\title{
Seroprevalence of antibodies to HTLV-I in patients with ocular disorders
}

\author{
Kumimko Nakao, Makoto Matsumoto, Norio Ohba
}

\begin{abstract}
Human T-lymphotropic virus type 1 (HTLV-I) has been shown to spread worldwide and to be responsible for distinct systemic diseases, namely adult $T$-cell leukaemia and HTLV-Iassociated myelopathy. Immune-mediated, inflammatory lesions in the lungs, joints, and lacrimal glands (Sjögren's syndrome) are also suggested to be associated with the retrovirus. We studied seroprevalence of antibodies to HTLV-I in patients with various ocular disorders who are residents of south-west Japan, one of the endemic areas of HTLV-I. Of 310 patients with ocular disease $72(23.2 \%)$ were seropositive. This seroprevalence did not differ significantly from that of the general population of the area. As regards individual ocular diseases, aetiologically undefined nonspecific uveitis showed a significantly high seropositivity for HTLV-I. Of 44 patients 18 $(\mathbf{4 0 . 9} \%)$ were seropositive. Their clinical features were acute or subacute, transient and sometimes recurrent, and granulomatous changes in the anterior uvea. Patients with isolated cotton-wool spot of the retina, nonfamilial retinitis pigmentosa, or keratoconjunctivitis sicca did not show any significantly high prevalence of HTLV-I infection.
\end{abstract}

Human T-lymphotropic virus type 1 (HTLV-I) is a recently defined retrovirus that may cause malignant disease of the blood (adult T-cell leukaemia),${ }^{1-3}$ and chronic neurological disease (HTLV-I-associated myelopathy or tropical spastic paraparesis). ${ }^{45}$ More recent studies also indicate that a diverse group of aetiologically unknown clinical disorders are probably associated with HTLV-I infection as well, including pulmonary alveolitis, Sjögren's syndrome, and arthropathy. ${ }^{5-8}$

HTLV-I has nothing to do with acquired immunodeficiency syndrome (AIDS), caused by a separate retrovirus HIV/HTLV-III, ${ }^{9}$ but has received much attention by many researchers. HTLV-I infection is worldwide, with endemic areas in south-west Japan, the Caribbean basin, central Africa, and Melanesia, and its main transmission routes include vertical transmission from infected mother to child, transfusion of infected blood, and sexual transmission..$^{58}$

Ocular disorders in patients with HTLV-Iassociated systemic diseases include intraocular opportunistic infections such as cytomegalovirus retinitis in immunocompromised patients with adult $\mathrm{T}$-cell leukaemia, ${ }^{10} 11$ and non-infectious anterior uveitis, microvascular changes of the retina, and retinochoroidal atrophic lesions in patients with HTLV-I-associated myelopathy. ${ }^{11-15}$
Our hospital is located in south-west Japan, where HTLV-I infection is highly endemic, and we see many patients infected with the retrovirus. We have therefore performed a prospective study of HTLV-I seroprevalence in patients with various ocular diseases. The main purpose of this study was to search for any ocular disorder with an unusually high seroprevalence of HTLV-I infection.

\section{Materials and methods}

A series of 310 patients, 158 men and 152 women, whose age ranged from 10 to 83 years (mean, 54.7, SD 17.3), were the subjects of a prospective study for HTLV-I infection. They were residents of Kagoshima prefecture of south-west Japan, and presented with various ocular diagnoses during a three-year period 1987-9 (Table 1). Infection with HTLV-I was examined by assessment of serum antibodies against HTLV-I by the method of particle agglutination (PA method) as described elsewhere. ${ }^{10}$ Agglutination reaction in serum of over 16 times dilution was regarded as seropositive, hence infected with the retrovirus. The patients also received a thorough ophthalmic and systemic examination.

The prevalence of HTLV-I infection in the general population of south-west Japan was studied by the PA method in a control group of 2484 adults -868 men and 1616 women, whose age ranged from 20 to 80 years (mean $55 \cdot 4$, SD 10.7).

The western blotting method (WB method) was also carried out on part of the material to confirm the accuracy of detection of the HTLV-I antibodies. Occasional materials showed inconsistency between the PA and the WB methods, though it was not so marked as to affect the conclusion in the present study.

The Mantel-Haenszel $\chi^{2}$ test $^{16}$ was used for statistical comparison between ocular diseases and general population in consideration of the age factor.

\section{Results}

Table 1 shows HTLV-I seroprevalence in patients with various ocular diseases, together with that in control adult residents of south-west Japan. Of 310 ophthalmic patients $72(23 \cdot 2 \%)$ were found to be infected with HTLV-I, the prevalence becoming higher with age. These results were compared with those for the general population of the same area, among whom 552 $(22 \cdot 2 \%)$ of 2484 control individuals were seropositive for HTLV-I, also with an increasingly high seropositivity with age. There was no significant difference in HTLV-I seroprevalence 
Table 1 Seroprevalence of antibodies to HTLV-I in various ocular disease

\begin{tabular}{|c|c|c|c|c|c|c|c|c|c|}
\hline \multirow[b]{2}{*}{ Ocular disease } & \multicolumn{9}{|c|}{ Seroprevalence (seropositive cases/total cases) } \\
\hline & $10-19$ & $20-29$ & 30-39 & $40-49$ & $50-59$ & $60-69$ & 70-79 & $80-89$ & Total $(\%)$ \\
\hline Specific uveitis entities & $0 / 3$ & $0 / 8$ & 2/9 & $1 / 10$ & $5 / 13$ & $2 / 10$ & $1 / 1$ & & $11 / 54(20 \cdot 4)$ \\
\hline Ocular sarcoidosis & $0 / 2$ & $0 / 4$ & & $1 / 3$ & $1 / 3$ & $1 / 2$ & $1 / 1$ & & $4 / 15$ \\
\hline $\begin{array}{l}\text { Harada's uveomeningitis } \\
\text { Behcet's disease }\end{array}$ & & $0 / 2$ & $0 / 3$ & $0 / 4$ & $3 / 5$ & $0 / 5$ & & & $3 / 19$ \\
\hline $\begin{array}{l}\text { Behçet's disease } \\
\text { Posner-Schlossman syndrome }\end{array}$ & & 0 & $1 / 2$ & $0 / 2$ & $\begin{array}{l}1 / 2 \\
0 / 1\end{array}$ & & & & 0/3 \\
\hline & & $0 / 1$ & $1 / 3$ & $0 / 1$ & & $1 / 1$ & & & $2 / 6$ \\
\hline $\begin{array}{l}\text { Fuchs's heterochro } \\
\text { Herpetic uveitis }\end{array}$ & & & & & $0 / 2$ & $0 / 1$ & & & $0 / 3$ \\
\hline $\begin{array}{l}\text { Herpetic uveitis } \\
\text { Non-specific uveitis }\end{array}$ & $0 / 1$ & & & & & & & & \\
\hline $\begin{array}{l}\text { Non-specific uveitis } \\
\text { Isolated cotton-wool spot }\end{array}$ & $1 / 4$ & $\begin{array}{l}1 / 4 \\
0 / 1\end{array}$ & $4 / 7$ & $\begin{array}{l}1 / 3 \\
0 / 1\end{array}$ & $4 / 8$ & $4 / 10$ & $\begin{array}{l}1 / 6 \\
0 / 4\end{array}$ & $2 / 2$ & $\begin{array}{l}18 / 44(40 \cdot 9)^{\star} \\
1 / 11(9 \cdot 1)\end{array}$ \\
\hline Retinal vascular occlusion & & & $0 / 1$ & $0 / 1$ & & $0 / 1$ & $0 / 1$ & $1 / 2$ & $1 / 7(14 \cdot 3)$ \\
\hline Senile macular degeneration & & & & $0 / 2$ & $1 / 1$ & $1 / 8$ & $3 / 6$ & $0 / 1$ & $5 / 18(28 \cdot 0)$ \\
\hline Retinitis pigmentos & & $0 / 1$ & $1 / 3$ & $1 / 9$ & $0 / 4$ & $4 / 10$ & $2 / 4$ & $0 / 1$ & $8 / 32(25 \cdot 0)$ \\
\hline Diabetic retinopath & & & & $0 / 1$ & $0 / 4$ & $0 / 5$ & $2 / 5$ & & $2 / 15(13 \cdot 3)$ \\
\hline njunctivitis sicca & & & $1 / 3$ & $1 / 5$ & $0 / 8$ & $2 / 9$ & & $0 / 1$ & $4 / 26(15 \cdot 4)$ \\
\hline Pterygium & & & & $0 / 1$ & $0 / 5$ & $0 / 4$ & $1 / 1$ & & $1 / 11(9 \cdot 1)$ \\
\hline Senile cataract & & & & $0 / 3$ & $0 / 4$ & $1 / 8$ & 7/12 & $2 / 8$ & $10 / 35(28 \cdot 6)$ \\
\hline Miscellaneous & $0 / 6$ & $0 / 3$ & $0 / 8$ & $1 / 6$ & $4 / 14$ & $5 / 14$ & $1 / 6$ & & $11 / 57(19 \cdot 3)$ \\
\hline Total & $1 / 13$ & $1 / 18$ & $8 / 31$ & $5 / 42$ & $14 / 62$ & $20 / 83$ & $18 / 46$ & $5 / 15$ & $72 / 310(23 \cdot 2)$ \\
\hline $\begin{array}{l}\text { General population seroprevalence } \\
\text { (\%) of HTLV-I }\end{array}$ & & $\begin{array}{l}3 / 21 \\
(14 \cdot 3 \%)\end{array}$ & $\begin{array}{l}16 / 135 \\
(11.9 \%)\end{array}$ & $\begin{array}{l}110 / 614 \\
(17.9 \%)\end{array}$ & $\begin{array}{l}189 / 878 \\
(21 \cdot 5 \%)\end{array}$ & $\begin{array}{l}172 / 646 \\
(32 \cdot 6 \%)\end{array}$ & $\begin{array}{l}57 / 175 \\
(26 \cdot 6 \%)\end{array}$ & $\begin{array}{l}5 / 15 \\
(33 \cdot 3 \%)\end{array}$ & $\begin{array}{l}552 / 2484 \\
(22 \cdot 2 \%)\end{array}$ \\
\hline
\end{tabular}

$\star$ Statistically significant $\mathrm{p}<0.01$ with the Mantel-Haenszel $\chi^{2}$ test. Others are not significant in comparison with general population.

between the ophthalmic group and the general population (Fig 1). But a group of ocular diseases were specially prevalent among those associated with HTLV-I infection and warrant discussion.

As regards endogenous uveitis, $11(20.4 \%)$ of 54 patients with specific clinical entities, including Behçet's disease and Harada's uveomeningitis, were infected with HTLV-I. However, this prevalence was not significantly higher than in the control population; this excludes any causative association with the retrovirus, though it might affect the clinical picture of ocular disease. On the other hand $18(40.9 \%)$ of 44 patients with non-specific, aetiologically undefined uveitis showed infection with HTLV-I. This prevalence was significantly higher than in the control group $\left(\chi^{2}=7 \cdot 62, \mathrm{df}=1\right.$, $\mathrm{p}<0.01)$, by the Mantel-Haenszel $\chi^{2}$ test $^{16}$ applied in consideration of the age-dependent increase of seroprevalence.

It is noticeable that non-specific uveitis in HTLV-I-infected patients was characterised by acute or subacute, mild granulomatous reactions in the anterior uveal tissue, such as Koeppe nodules and mutton-fat keratic precipitates with or without vitreous opacities, and that the disease subsided in a few weeks in an apparent response to local or systemic corticosteroids. Two of 18 such patients showed recurrent uveal reactions. All these HTLV-I-infected patients with characteristic uveitis remained otherwise normal in physical and laboratory studies during up to three years' follow-up. Case reports of some of these patients are given

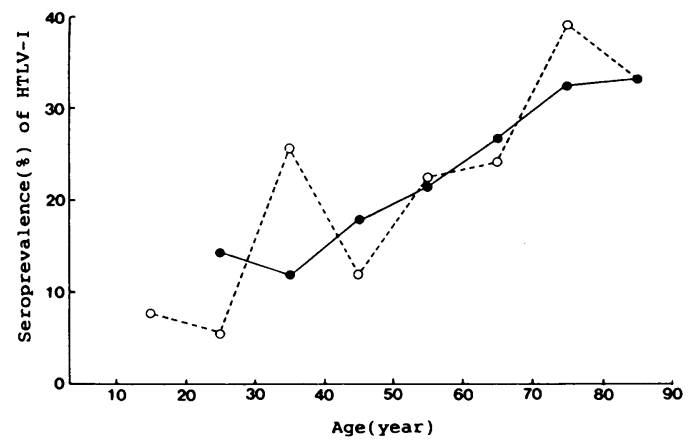

elsewhere. ${ }^{12}$ The following is an additional representative case.

\section{CASE REPORT}

A 32-year-old man complained of acute blurring of vision in the left eye. The corrected visual acuity was 20/20 in the right eye and 20/40 in the left eye. Slit-lamp examination revealed in the left eye granulomatous uveitis, showing $1+$ cells in the anterior chamber, $2+$ mutton fat keratic precipitates, and granular vitreous opacities. Four weeks' topical and systemic corticosteroid therapy brought about diminution of the inflammatory signs, and the visual acuity returned to $20 / 20$. The patient remained normal in systemic and laboratory studies throughout the follow-up period of two years except for a seropositivity for HTLV-I.

Of 11 patients who showed isolated, asymptomatic cotton-wool spots or mild retinal microvasculopathy but had no accountable local or systemic disease one was found to be infected with HTLV-I.

Of 32 patients with non-familial, isolated retinitis pigmentosa, eight $(25 \cdot 0 \%)$ had serum antibodies to HTLV-I, thus indicating no significant increase in HTLV-I seroprevalence over the control group.

As regards keratoconjunctivitis sicca, four $(15 \cdot 4 \%)$ of 26 patients showed HTLV-I infection, representing no significant increase in HTLV-I prevalence.

\section{Discussion}

The prevalence of HTLV-I infection is strikingly high in south-west Japan. Yet the majority of infected adults remain carriers without any overt clinical disease, as epidemiological studies indicate that only one in 1000-2000 infected individuals may suffer from malignant disease of blood or chronic neurological disease. ${ }^{517}$ In any case we should be cautious in interpreting the high seroprevalence in ocular diseases in terms of the virus's causative role. Indeed most of the ocular diseases studied here showed no statistically significant increase in prevalence over the
Figure 1 Seroprevalence of
antibody to $H T L V$-I in a general population (closed circles: $n=2484$ ) and patients with various ocula disorders (open circles: $n=$ 310) plotted against age in years. 
control population. Some comments may, however, deserve mention on a certain group of ocular disorders.

HTLV-I infection has received particular attention in recent years because, in addition to obvious systemic diseases (adult T-cell, leukaemia and HTLV-I-associated myelopathy), various aetiologically unknown disorders such as pulmonary alveolitis, arthropathy, Sjögren's syndrome, and myositis have been suggested to be involved in HTLV-I infection. A probable mechanism is thought to reside in immune mediated tissue reactions through polyclonal activation of $\mathrm{T}$ and $\mathrm{B}$ cell functions. ${ }^{58}$ In this connection the present observations appear of substantial interest, in that patients with aetiologically undefined, non-specific uveitis showed a significantly high seroprevalence of HTLV-I, and that the clinical features had an acute or subacute onset, consisted of granulomatous lesions in the anterior uvea, responded to local and/or systemic corticosteroid, and possibly ran a recurrent course. It is also emphasised that these patients remained otherwise intact in physical and laboratory studies. In particular we have found similar uveal disease in patients who had HTLV-I-associated myelopathy. ${ }^{11}{ }^{12}$ It would therefore be plausible that uveal inflammatory disease should occur as an isolated form in close association with HTLV-I infection, and we are inclined to hypothesise HTLV-I-associated uveitis (HAU), though its pathogenesis remains to be defined.

Isolated cotton-wool spots or microvascular changes of the retina are seen in some patients with HTLV-I-associated myelopathy. ${ }^{11}$ 14 In the present study we focused our attention on those patients who showed such retinal changes but did not show any accountable local or systemic disorder. One of nine such patients were found to be infected with HTLV-I. Further studies are justified to explore whether an isolated form of retinal microangiopathy is associated with HTLV-I infection.

We previously reported four cases of retinochoroidal degenerative changes which were found in 36 patients with HTLV-I-associated myelopathy, and discussed whether those cases represented a causative rather than a fortuitous association with HTLV-I infection, though the mechanism remained undefined. ${ }^{13}$ The observations prompted us to examine HTLV-I seroprevalence in those patients who had isolated, aetiologically unknown, non-familial retino- choroidal degeneration (retinitis pigmentosa): and as a result eight of 32 cases were found to be infected with the retrovirus. This degree of seroprevalence does not differ from that in the general population, but the finding may neither upset nor support a hypothesis that HTLV-I infection may involve retinochoroidal changes phenotypically similar to hereditary disease.

Infection with HTLV-I is now recognised to be worldwide. ${ }^{58}$ Ophthalmologists should be aware of this newly defined retrovirus as well as another retrovirus human immunodeficiency virus (HIV/HTLV-III) causing acquired immunodeficiency syndrome. ${ }^{9}$

This study was supported by a grant in aid for scientific research (No. 634480396) from the Japanese Ministry of Education, research from the Japanese Ministry of Health and Welfare.

1 Uchiyama T, Yodoi J, Sagawa K, Takatsuki K, Uchino H Adult T-cell leukemia: Clinical and hematologic features of 16 cases. Blood 1977; 50: 481-92.

2 Hinuma $Y$, Nagata $K$, Hanaoka $M$, et al. Antigen in an ATL cell line and detection of antibodies to the antigen in human sera. Proc Natl Acad Sci USA 1981; 78: 6476-80.

3 Yoshida M, Miyoshi I, Hinuma Y. Isolation and characterization of retrovirus from cell lines of human adult $T$-cell leukemia and its implication in the disease. Proc Natl Acad Sci USA 1982; 79: 2031-5.

4 Osame M, Matsumoto M, Usuku K, et al. Chronic progressive myelopathy associated with elevated antibodies to HTLV-I and adult T-cell leukemialike cells. Ann Neurol 1987; 21 : 117-22.

5 Román GC, Vernant TC, Osame M. HTLV-I and the nervous system. New York: Liss, 1989.

6 Vernant JC, Buisson G, Magdeleine J, et al. T-lymphocyte alveolitis, tropical spastic paraparesis, and Sjögren syndrome. Lancet 1988; i: 177

7 Maruyama M, Sakashita I. HTLV-I associated bronchopneumonopathy - a new clinical entity. Am Rev Resp Dis 1989 ; 137: 46 .

8 World Health Organisation. Report of Scientific group on HTLV-I infections and associated diseases. Manila, Philippines: World Health Organisation Regional Office for the Western Pacific, March 1989.

9 Shuman JS, Orellana J, Friedman AH, et al. Acquired immunodeficiency syndrome (AIDS). Surv Ophthalmol immunodefiency

10 Kabayama Y, Isashiki M, Uehara F, Ohba N. Ocular disorders associated with adult T-cell leukemia. Rinsho Ganka (Fpn $\mathcal{F}$ Clin Ophthalmol) 1988; 42: 139-41.

11 Ohba N, Matsumoto M, Sameshima M, et al. Ocular manifestations in patients infected with human T-lymphotropic virus type 1 (HTLV-I). fpn $\mathcal{f}$ Ophthalmol 1989; 33: 1-12.

12 Nakao K, Ohba N, Matsumoto $M$. Noninfectious anterio uveitis in patients infected with human T-lymphotropic virus type 1. fpn $\mathcal{F}$ Ophthalmol 1989; 33: 472-81.

13 Nakao $\mathrm{K}$, Ohba $\mathrm{N}$, Isashiki $\mathrm{M}$, et al. Pigmentary retinal degeneration in patients with HTLV-I-associated myelopathy. Fpn f Ophthalmol 1989; 33; 383-91.

14 Nakao K, Uemura A, Hirashima S, Unoki K. Cotton-wool spots on the retina in patients infected with human $T$ lymphotropic virus type 1 (HTLV-I). Folia Ophthalmol $f$ pn lymphotropic virus

15 Sasaki K, Morooka I, Inomata H, Kashio N, Akamine T, Osame $M$. Retinal vasculitis in human T-lymphotropic virus type 1 associated myelopathy. Br $\mathcal{f}$ Ophthalmol 1989; 73: 812-5.

16 Kirkwood BR. Essentials of medical statistics. Oxford: Blackwell, 1988.

17 Tajima K, Tominaga S, Suchi T. Epidemiological analysis of the distribution of antibody to adult T-cell leukemia-virusassociated antigen: possible horizontal transmission of adult T-cell virus. Fpn f Cancer Res 1982; 73: 893-901. 